\title{
MANAGEMENT TECHNOLOGY FOR HOSPITAL INPATIENT CARE UNITS ${ }^{1}$
}

\author{
Jorge Lorenzetti ${ }^{2}$, Francine Lima Gelbcke ${ }^{3}$, Lara Vandresen ${ }^{4}$
}

\footnotetext{
${ }^{1}$ Result of the dissertation - "PRAXIS": management technology for inpatient care units, presented to the Programa de Pós-Graduação em Enfermagem (PEN), Universidade Federal de Santa Catarina (UFSC), in 2013.

${ }^{2}$ Ph.D. in Nursing. Professor, Departamento de Enfermagem, UFSC. Florianópolis, Santa Catarina, Brazil. E-mail: jorgelorenzetti@ hotmail.com

3’Ph.D. in Nursing. Professor, Departamento de Enfermagem, UFSC. Florianópolis, Santa Catarina, Brazil. E-mail: fgelbcke@ccs.ufsc.br

${ }^{4}$ 'Master's student in PEN/UFSC. Florianópolis, Santa Catarina, Brazil. E-mail: laravandresen@hotmail.com
}

\begin{abstract}
In Brazil there are over 18.5 million hospitalizations every year. Inpatient care units lack management technology that is capable of providing both users and professionals with a better experience. The PRAXIS management system fulfills this demand. The software is registered under patent 14196-6. This article's objective is to describe the PRAXIS technology and its construction process and to analyze its results after one year of use in an inpatient care unit. Methodological research served as the basis for creation of the software, and quasi-experimental study realized for the intervention in an inpatient care unit. Results present the structure of the technology and the effects of its implementation. Some aspects that emerged were improvements in the unit's performance linked to participative planning, care processes management, human resources management, resource management, quality control, and use of the electronic panel. The nursing team and an external assessment committee positively evaluated the technology. Its consolidation requires a maturation process, because it is a valuable and innovative resource for the performance of inpatient care units.
\end{abstract}

DESCRIPTORS: Inpatient care units. Health management. Quality of health care. Nursing informatics.

\section{TECNOLOGIA PARA GESTÃO DE UNIDADES DE INTERNAÇÃO HOSPITALARES}

\begin{abstract}
RESUMO: No Brasil acontecem mais de 18,5 milhões de internações ano. As unidades de internação carecem de uma tecnologia de gestão que favoreça melhor experiência para os usuários e profissionais. O sistema de gestão PRAXIS supre esta lacuna, um software que recebeu a patente 14196-6. O objetivo do presente artigo é descrever a tecnologia PRAXIS e seu processo de construção e analisar sua aplicação após um ano de seu uso em uma unidade de internação. A pesquisa metodológica foi suporte para criação do software e para estudo quase-experimental. Os resultados apresentam a estrutura da tecnologia e efeitos da implantação. Os aspectos evidenciados são benefícios para desempenho da unidade com o planejamento participativo, gestão de processos assistenciais, gestão de pessoas, gestão de materiais, gestão da qualidade e uso de painel eletrônico. A tecnologia foi avaliada positivamente pela equipe de enfermagem e comissão externa de avaliação. A consolidação necessita maturação, por ser um recurso valioso e inovador para o desempenho das unidades de internação.
\end{abstract} DESCRITORES: Unidades de internação. Gestão em saúde. Qualidade da assistência à saúde. Informática em enfermagem.

\section{TECNOLOGÍA PARA GESTIÓN DE UNIDADES DE INTERNACIÓN HOSPITALARIAS}

RESUMEN: En Brasil ocurren más de 18,5 millones de internaciones anuales. Las unidades de internación carecen de tecnologías de gestión que permitan mejores experiencias para pacientes y profesionales. El sistema de gestión PRAXIS suple esa brecha, el software recibió la patente 14196-6. El próposito de este artículo es describir la tacnología del PRAXIS y su proceso de contrucción y análisis de su solitud, después de un año de uso en una unidad hospitaria. El programa fue creado con soporte en la investigación metodológica, y de la cuasi-experimental para intervención en unidad de internación. Los resultados expresan la estructura de la tecnología y efectos de su implantación. Los aspectos evidenciados son beneficios de desempeño en la unidad, con planificación participativa, gestión de procesos de atención, gestión de personal, de materiales, de calidad, y uso de panel electrónico. La tecnología recibió apreciación positiva del equipo de enfermería y la comisión externa evaluadora. El proyecto precisa maduración para constituirse en recurso valioso e innovador para desempeño en las unidades de internación.

DESCRIPTORES: Unidades de internación. Gestión en salud. Calidad de la atención de salud. Informática aplicada a la enfermería. 


\section{INTRODUCTION}

Meeting society's demands for quality, safe, universal health services and the permanent availability of new technologies fuels the increasing costs of the sector and demands proper and innovative management practices.

Traditionally, healthcare management has focused on institutional organization so that professionals, especially physicians, could perform care with great autonomy. ${ }^{1}$ Currently, in the context of a movement towards effectiveness, quality, and efficiency in care, management has significantly expanded its reach, which requires the integration of different services and their care processes. ${ }^{2}$ From this perspective, the healthcare system is responsible for setting the standards of care offered to the population, and the various healthcare organizations are responsible for the effectiveness, quality, and efficiency of services that are part of their mission. This change has great implications, because care processes are no longer under the absolute control of health workers, but have become the organizational goal, made palpable through standards and required protocols under permanent development and revision. ${ }^{3}$

Nursing work is very relevant, being responsible, in general, for the organization, maintenance, and coordination of operative procedures in a variety of therapeutic environments. Nursing work coordinates the work of various health professionals and has great responsibilities in providing necessary care resources.

Inpatient care units are places where necessary care is administered to patients whose health demands require hospital admission. Therefore, they are relevant locations for the results of care offered to the population. It is possible to estimate the occurrence of over 18.5 million hospital admissions per year in Brazil. ${ }^{4-5}$ The coordination/ management/leadership of inpatient care units is the role of nurses.

It can be observed that the management of inpatient care units carries with it either a complete lack of or very little global planning, difficulties with the coordination of various care and administrative processes, the absence of regular practices of classification of users' care demands and the corresponding allocation of necessary care professionals, little or no systematic assessments of administrative and care performance, communication issues, and an absence of instruments for sustainable participative management. There is a need for technology that meets these demands, becomes part of care and administrative processes, continually improves performance, encourages integrated and multidisciplinary care, and places the patient in a central role in the process of health recovery. This would have a positive impact on both care quality and the work environment.

It should be emphasized that there is an almost complete absence of studies addressing the management of inpatient care units as a whole, in other words, as care units considered privileged spaces for the direct care and performance of most hospitals' goals.

The reasons that motivated the decision to build a management technology for inpatient care units were the great responsibility that nursing holds in the whole of the work developed in inpatient care units, the relevance of these spaces for the care offered to the population, and the absence of proper management standards for these care units.

This is an integrated and computer-based project for the management of inpatient care units. It facilitates advances by employing an innovative and participative management instrument, a joint effort of theory and practice involving the production of an app or software for management of inpatient care units titled PRAXIS. The name PRAXIS conveys the ambition, from the contemplation of management practices in inpatient care units, of building and applying management technologies that seek to positively transform the current situation. It has the goal of establishing management standards for inpatient care units, focused on a nursing care approach that is comprehensive, humanized, safe, and of quality. The creation of this management technology for inpatient care units was guided by the principles of participative management, continuous performance improvement, and technological innovation for management of these relevant care spaces.

This article's objective is to describe the PRAXIS technology and its construction process and to analyze its results after one year of use in an inpatient care unit.

\section{METHOD}

The goal of constructing, experimenting with, and assessing the technology for management of inpatient care units was made possible by a history 
of software development and its experimentation and assessment of benefits and limitations in an inpatient care unit.

The chosen method for the study was the mixed approach. Methodological research, which is appropriate for the development of instruments ${ }^{6}$ such as software and is also a reference in international standards, guided the creation of PRAXIS, specifically when it came to following Rule NBR ISO/IEC 12207.7 Quasi-experimental research gave support for applying PRAXIS technology to the concrete reality of an inpatient care unit. Quasi-experimental research is widely recognized as a guide for interventional studies, which preserve methodological rigor while allowing for a certain flexibility in comparison to experimental research. ${ }^{8}$ The quasi-experimental method is especially widely employed in health informatics' field research. ${ }^{9}$ In this case, the quasiexperimental research category with the design "One-group Posttest Only Design" was used. ${ }^{9}$ This option is frequently used in healthcare for the introduction of new software, as with PRAXIS. It makes it possible to assess and measure the impacts of a given intervention.

PRAXIS's development used the reference mentioned above, Information TechnologySoftware Life Cycle Processes, which organizes processes into the following phases: requirement gathering and analysis; functional specification; architecture project; development and tests; and implementation and maintenance. ${ }^{9}$ The application was developed for the web environment and is compatible with Internet Explorer, Mozilla Firefox, and Google Chrome on desktops, notebooks, and tablets. This technology does not replicate the features of other hospital management software, electronic medical records, and patient flow management, but interacts with them to fill a specific role in managing inpatient care units.

The software is innovative in its field, which is proved by patent N 14196-6, from April 2014, by the Instituto Nacional de Propriedade Industrial (INPI).

A team of technicians worked for 18 months, from October 2011 to March 2013, to build the software. The team was composed of a systems analyst, two programmers, and one intern. The programmers and the intern were provided by the university hospital (UH), which was a partner in the creation of the technology. As a starting point, the researcher prepared a detailed descriptive list of the system's requirements, based on PRAXIS' guiding principles, which were structured in the following technology components: the unit's participative planning (UPP); management of care processes (MCP); human resources management in the nursing team (HRM); resource management (RM); quality control (QC); and a dashboard in the nursing station (detailed in Figure 1). The system and structure of this knowledge and these methods result from experience with the realities of management in inpatient care units. In the quasiexperimental design, these can be considered an informed previous observation of a reality in need of a given intervention.

PRAXIS was set up in an adult medical clinic at a university hospital in southern Brazil. In January 2013, the necessary electronic equipment was installed in the unit and, in April 2013, its operation began. This equipment remains in place to this day.

Participation of the nursing team was achieved through the following initiatives: information; awareness raising; filling out and signing a free and informed consent form; participation in discussion workshops with the unit's team to create the UPP; and training for the system as a whole. With this, the unit's information was entered into the PRAXIS system, the software was set up and used in the unit, and necessary adjustments were made during the implementation process. The technology was preliminarily assessed using the unit's team's opinion through anonymous forms and decisions from an external assessment commission composed of three managers in the nursing sector. Research was approved by the Human Research Ethics Committee of the Universidade Federal de Santa Catarina, document N 2401.

\section{RESULTS}

Results were organized into two macro aspects: description of relevant features of the technology itself and analysis of the effects of its practical use.

\section{Software components}

PRAXIS technology integrates management of care and administrative processes that are necessary in inpatient care units. The software's features can be visualized in the following figure 1 : 


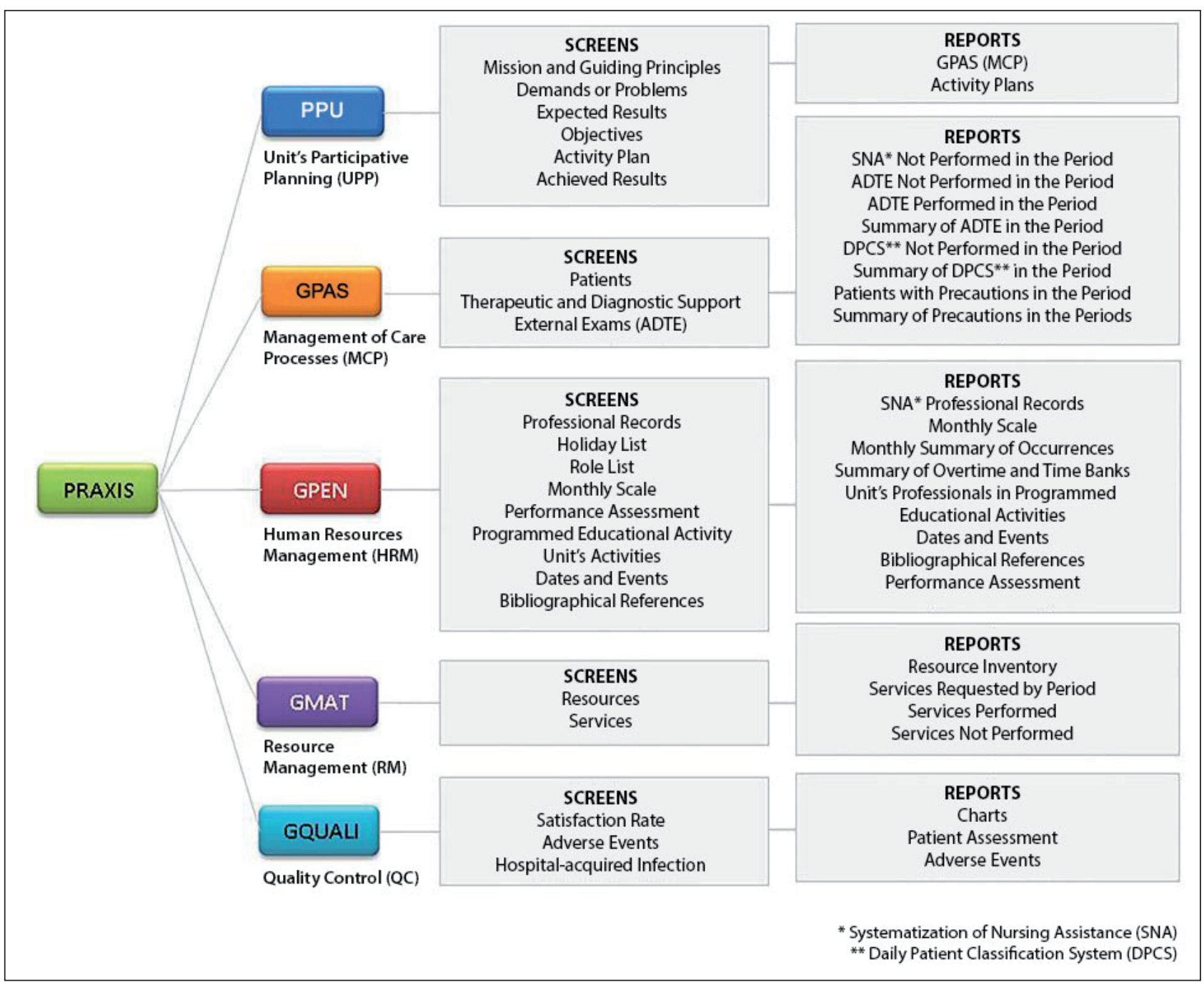

Figure 1 - General view of PRAXIS. Florianópolis-SC, Brazil, 2013

The application involves the execution of basic administrative instruments in inpatient care units: planning; organization; operationalization; and result assessment. As such, it combines material and non-material technologies in a computer- ized system. It also required the creation of new methodologies and the structuring of knowledge in innovative types of use.

Figure 2 shows the software's starting screen.

\begin{tabular}{|c|c|c|c|c|c|c|c|c|c|}
\hline & & & & $\begin{array}{l}\text { istema d } \\
\text { sspital: Hospital } \\
\text { nidade: Unidade }\end{array}$ & $\begin{array}{l}\text { Gestão de } \\
\text { Universitário Polydoro } \\
\text { Clinica Médica } 2\end{array}$ & $\begin{array}{l}\text { nidades de I } \\
\text { nani de São Thiago }\end{array}$ & Iternação Hos| & italares & \\
\hline 四 PPU & III GPAS & 而 GPEN & II GMAT & [III GQUALI & Categoria de Cuidado & (11) Painel Eletrônico & III Painel Escala Mensal & UII Sair & \\
\hline Praxis - ve & & & & & & & & (4) Hora login: 13:19 (1) Tempo sessão: $30.0 \mathrm{~m}$ & \& seja bem-vindo, jorge. \\
\hline
\end{tabular}

Figure 2 - Starting Screen of PRAXIS. Florianópolis-SC, Brazil, 2013

Permanent identification of the care profile required by each patient is an essential care management device in inpatient care units. Classification of patients into degrees of care (minimum, intermediary, high-dependency, semi-intensive, and intensive) is crucial for adequate organization of care and allocation of necessary nursing professionals. PRAXIS technology incorporates this device and facilitates its daily use. Figure 3 shows the classification screen. 


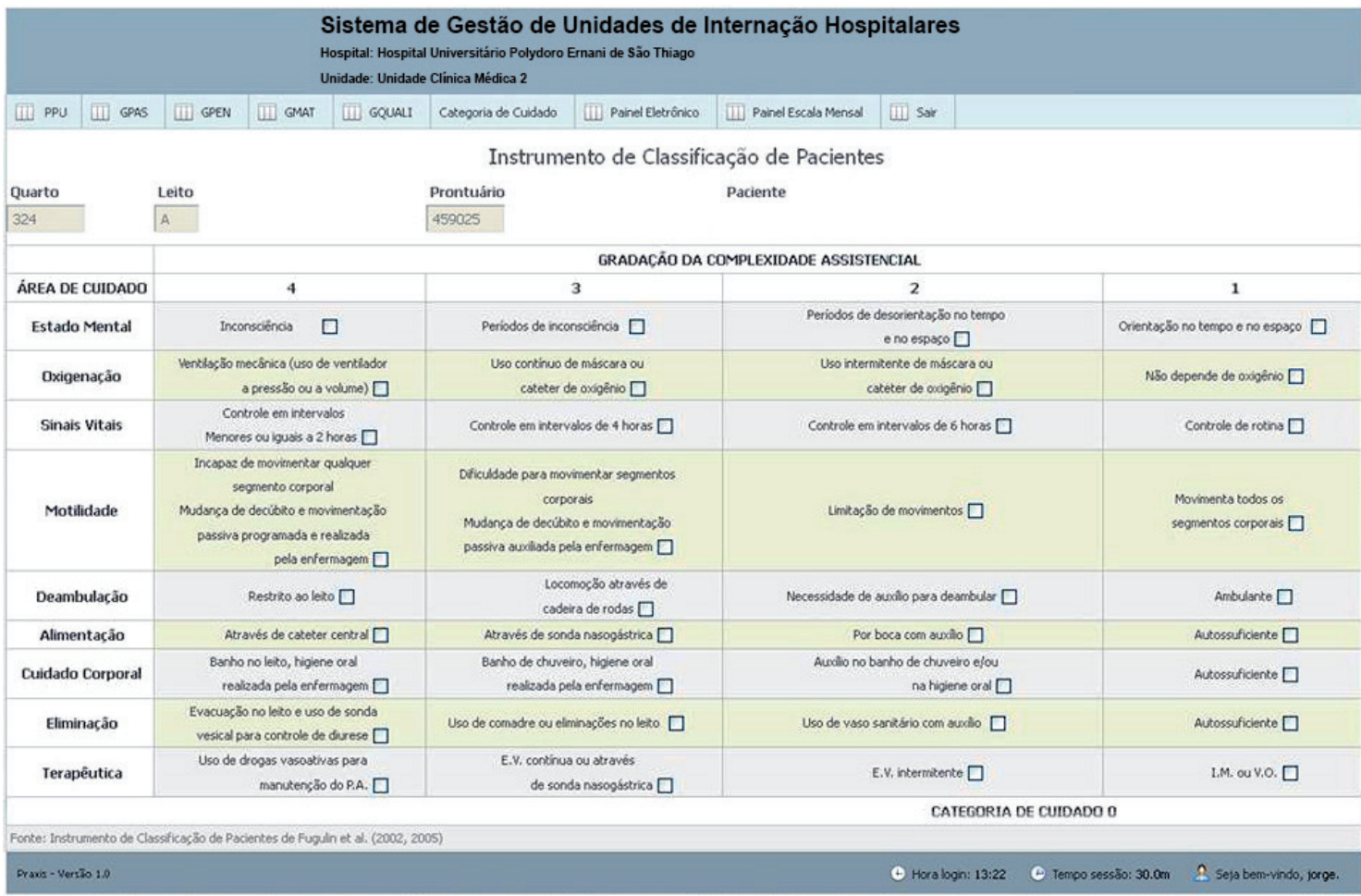

Figure 3 - Patient classification screen. Florianópolis-SC, Brazil, 2013

A significant strength of the technology is the unprecedented use of a dashboard, a 50" TV, at the nursing station in inpatient care units. This dashboard displays patient status, indicating care categories required for the day: intensive or semiintensive (red); high-dependency (yellow); interme- diary (blue); and minimum (green). Other relevant information is organized and displayed with up-todate information for viewing and communication among nursing team members and other health professionals, users, companions, families, and visitors. Figure 4 shows the dashboard:

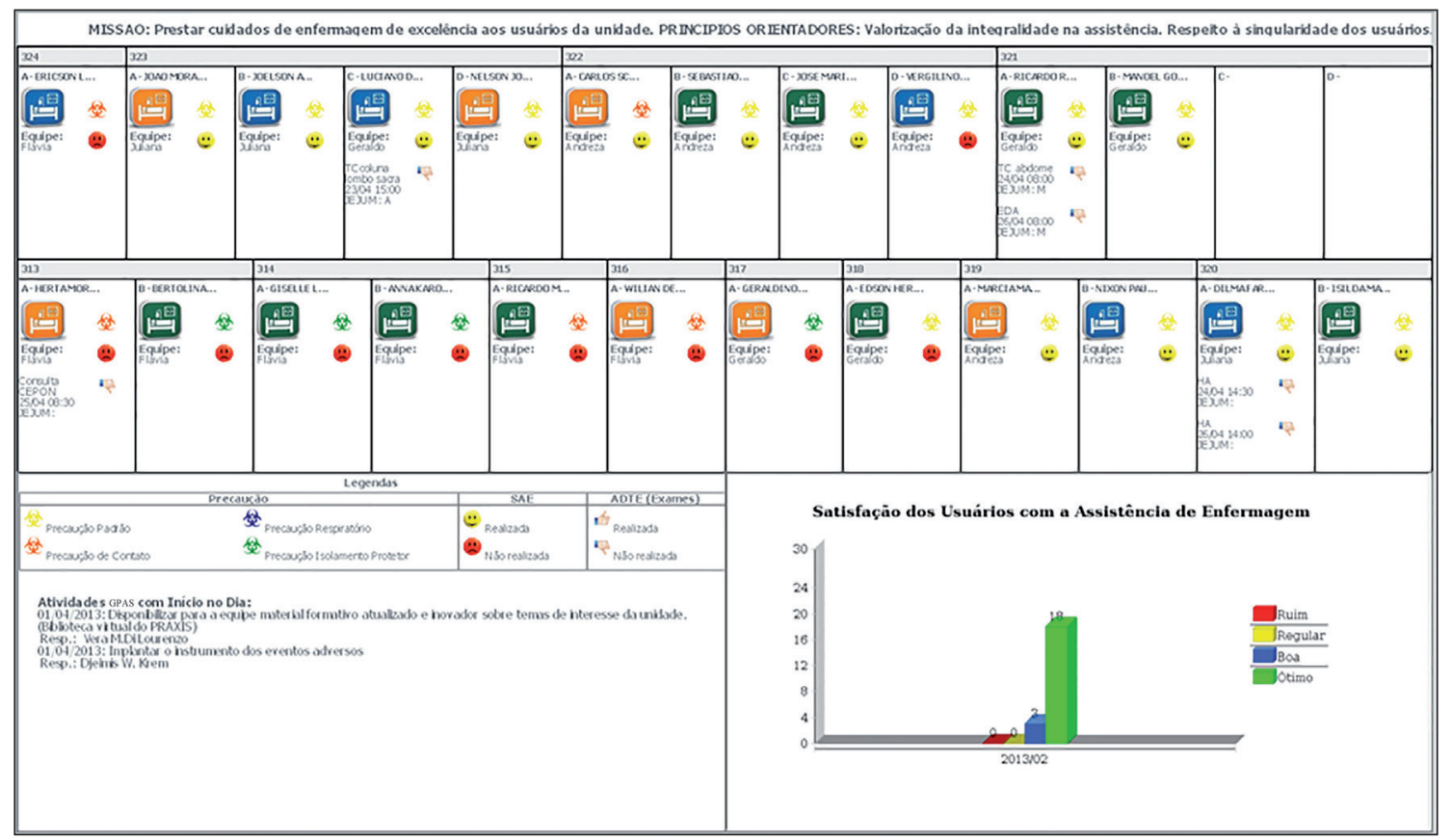

Figure 4 - Dashboard. Florianópolis-SC, Brazil, 2013 
PRAXIS technology brings together a variety of the care and administrative processes of inpatient care units in addition to those mentioned before. It proposes a UPP methodology, which supports participative management and is highly regarded in healthcare but that still faces difficulties in terms of sustainable adoption. It provides a monthly electronic scale, in addition to other demands of HRM, such as performance assessment and permanent education. It enables RM and control of the units' maintenance and infrastructure services. It highlights the units' performance by incorporating eight result indicators (GQUALI): user satisfaction with nursing care; coverage rate of systematization of nursing assistance (SNA); rate of performance of exams and external procedures; rate of hospital-acquired infections in the unit; occupancy rate in the unit; mean admission length; mean number of patients per day; and adverse events.

\section{Technology Application}

PRAXIS technology has been in use at a medical clinic at the University Hospital since April 2013. In the following section, the intervention's findings are presented, along with their assessment. In the discussion, the main effects observed up to April 2014 are analyzed.

Unit's Participative Planning (UPP): the nursing team designed the UPP by approving work plans for problems and demands. The eight priorities and their respective percentage of con- clusion up to April 2014 are: daily classification of patients $(100 \%)$; procedure manual $(20 \%)$; training (30\%); companionship policies $(30 \%)$; quality of working life (70\%); resource management $(70 \%)$; sustainable practices $(10 \%)$; and excellence in care $(70 \%)$.

Daily Patient Classification System (DPCS): as an essential resource for the management of nursing care in the daily organization service and the allocation of nursing professionals, the PRAXIS management system enabled daily classification of all inpatients and their photographs could be viewed on the electronic panel in the nursing station (Figure 4).

The unit has 25 beds and the mean number of patients per day was 21.63. Inpatients were distributed in the following care categories in the period from April 2013 until April 2014: 44\% of patients under minimum care; $28 \%$ of patients under intermediary care; $27 \%$ under high-dependency; $0.7 \%$ under semi-intensive care; and $0.3 \%$ under intensive care.

Daily inpatient classification is essential for calculating total hours of nursing care required by patients per day and fundamental for the allocation of professionals. Figure 5 shows the total average nursing hours (143.86h) required in the unit, based on the classification of patients in care categories and using parameters established in Conselho Federal de Enfermagem N293/2004 as well as what is recommended in the literature, which is 12 hours of nursing care for patients in situations of high dependency. ${ }^{10-11}$

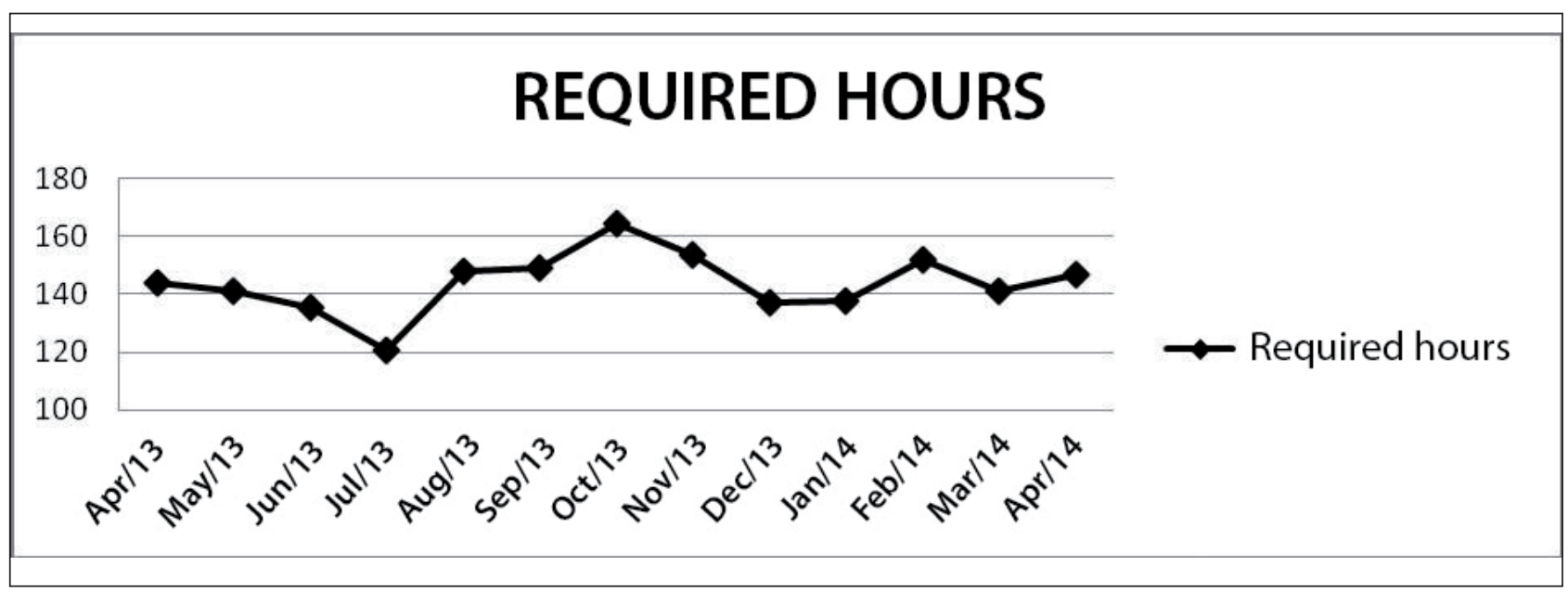

Figure 5 - Total monthly nursing hours required per day for inpatients in the unit in the period of April 2013 to April 2014. Florianópolis-SC, Brazil, 2014 
Number of nursing professionals: daily calculation of nursing hours required by inpatients makes it possible to allocate the number of professionals necessary in the unit. The mean required nursing hours by month is 143.86 , based on data gathered in the period from April 2013 to April 2014. This was calculated by adopting the following criteria: to consider $85 \%$ of effective work time; $25 \%$ nurses and $75 \%$ nursing assistants and technicians; and a $65 \%$ rate of technical safety for 30 work hours per week. ${ }^{11}$ The number of professionals required in the unit in the period between April 2013 to April 2014 and the number of professionals in April 2014, respectively was: nurses 12 and nine; nursing technicians/assistants 35 and 27.

Unit's performance: continuous improvement of performance is an important guiding principle of the PRAXIS management system for inpatient care units. Accordingly, it has the GQUALI component, which is dedicated to tracking eight performance indicators in the unit. These indicators' results are permanently displayed in rotation and continually updated in a specific area of the electronic panel at the nursing station.

User satisfaction with service is a mandatory indicator in all methods of quality assessment in healthcare. In this management technology, all users are invited to complete a nursing care assessment questionnaire at discharge. This research has been conducted since PRAXIS technology went online. From the first 13 months (April 2013 to April 2014), we highlight two out of eight aspects in this article: general assessment of offered nursing care; and the main reasons for satisfaction and dissatisfaction with offered nursing care. On a zero to ten scale, $76 \%$ of patients rated the care as great, $22 \%$ as good, $2 \%$ regular, and none considered it bad. The most frequently mentioned reasons for satisfaction were: the professionals' good attitude; attention and kindness; better care than in other hospitals; very good commitment and personal treatment; well performed care; and others. The most frequently mentioned reasons for dissatisfaction were: slow service; low number of professionals; lack of explanations; little guidance for family members; inadequate daily cleaning; and the need of a higher attention towards unaccompanied patients, among others.

Risk management in care is another mandatory component for the quality of all health services. It is imperative that this aspect is present in direct care in all inpatient care units. PRAXIS technology incorporates records and treatment of adverse events that directly affect nursing care, such as: falls; pressure ulcers; medication errors; and others. Internalizing this procedure in daily practice represents a great challenge, but small advancements have occurred, with records of 1.4 adverse events per month in the previously mentioned period (mean).

The inpatient unit where PRAXIS is used is very susceptible to hospital-acquired infections, because immunosuppressed patients are treated there, as well as patients undergoing chemotherapy and infected clinical patients. The system's electronic panel shows which infection precautions are to be observed for each bed, as well as infection rates in the last three months. The mean monthly infection rate in the unit in the months of 2013 under study was $24.95 \%$. In the months of 2014 , it was $18.35 \%$.

PRAXIS technology created two innovative performance indicators for inpatient care units: systematization of nursing assistance (SNA) coverage rate; and performance rate of diagnosis and therapy procedures outside the unit. The first has the goal of verifying how many patients are covered by daily nursing updates. The second has the goal of identifying and avoiding the reasons for not performing planned exams and procedures that cause patient discomfort, increase in stay length, and financial losses, among others.

The unit's electronic panel has a feature for visualization of patients who have already had their nursing updates performed for the day and for organization of the daily schedule of planned external exams and procedures. The coverage rate of SNA in the unit in this period was $73.07 \%$ and the rate of exams and procedures performed in comparison to what was expected was $93.77 \%$. The main causes for nonperformance were medical criteria, communication errors, and problems at the service facilities due to perform exams, among others.

The remaining performance indicators in the unit had the following results: occupancy rate of $86.52 \%$; mean number per day of 21.63 patients for 25 beds in use in the unit; and average stay of 11.55 days.

PRAXIS technology assessment: Preliminary assessment from the facility's health team using the technology is very positive. Another highlight is the conclusion of an External Assessment Commission, composed of two manager nurses from the same hospital and one manager nurse from 
another hospital: the instrument presented to the inpatient care unit was coherent with the proposed objective, since the technology was introduced, used and assessed while addressing the goal of innovation in nursing management, seeking to positively transform current care. Concerning PRAXIS's weak points, there was a consensus that instabilities in the unit's network infrastructure, which cause frequent drops in the system, harm its functionality.

\section{DISCUSSION}

Hospital care is very complex because it involves attention to people suffering critical and acute health risks. It also demands the use of exclusive technologies and a specialized and advanced multi-professional approach, with care protocols that are valid, reliable, safe, and up to date.

Due to risks, costs, and type of environment, hospitalizations require special tools. Because of this, there is a tendency for inpatient profiles to be increasingly more serious, clinically unstable, and in need of more complex surgical interventions. ${ }^{12-13}$

Nursing work has a relevant role in the outcome of hospital care and the higher complexity of inpatients' statuses results in a higher workload for its professionals. ${ }^{13-15}$

The structure of nursing teams, both in terms of adequate numbers and appropriate skills / degrees, is considered a precondition for good results in hospitals. Many studies show a correlation between these variables and the quality of hospital work, especially for indicators directly affected by nursing work. ${ }^{16-19}$ Hospital death rates would be influenced by this, as shown in a study ${ }^{16}$ where hospitals that had one nurse for six patients and $60 \%$ of bachelor nurses had $30 \%$ fewer deaths than hospitals with one nurse for eight patients and only $30 \%$ of bachelor nurses.

Inpatient care units are where hospital care is focused, therefore, have a crucial role in the results for patients. Nurses, in general, are the managers of these care spaces, and they must guarantee continuous care for inpatients. Research and knowledge applied in managing care and administrative processes inherent to inpatient care units focus aspects or parts of their governance. PRAXIS technology for management of inpatient care units is an innovative solution whose aim is to integrate essential processes in the management of these care units, resulting in benefits for care and improvement of the work environment. Thus, it strongly adheres to the international challenge of building favorable and positive practice environments that support safe and quality care. Nurses have a crucial role in the transformation and improvement of work environments for the profession. ${ }^{20-21}$

PRAXIS technology structures the use of administrative instruments in inpatient care units. A basic tool is planning. PRAXIS offers a UPP methodology, which is the device that enables participative management (PM) in the units.

Brazil's Unified Health System (SUS) adopted PM as a general guideline, and the Ministry of Health has the National Secretariat of Strategic and Participative Management (SPM) and the National Policy for Strategic and Participative Management in SUS (ParticipaSUS). ${ }^{22} \mathrm{PM}$ is also one of the main axes of the National Policy for Humanization in SUS (HumanizaSUS). ${ }^{23}$ Internalization of the practice of planning in inpatient care units is still a challenge to be pursued, involving culture changes and appreciation of the managers' leadership in these important care spaces. PRAXIS technology can be a facilitating base for such organizational transformation.

In Brazil, it can be observed that inpatient care units, in general, do not use valid and objective instruments for patient classification and also do not use scientific bases for adequate allocation of necessary professionals. Studies show the existence of stressors, work overloads, a high number of absences, demotivation, accidents, and occupational diseases that generate professional dissatisfaction among nursing professionals. ${ }^{24-25}$ Therefore, inpatient care units are frequently negative work environments; they are unfavorable for professionals and amplify negative results for safety and quality of care.

Distribution of the unit's patients in care categories, assessed in this 13 month period in the unit, is similar to what was found in another study ${ }^{26-27}$ in the medical clinic unit of a university hospital: 45.9 and $45.79 \%$ for minimum care patients; $24.8 \%$ and $26.08 \%$ for intermediary care patients; and $29.2 \%$ and $25.79 \%$ for high-dependency care patients. These studies emphasize the significant incidence of high-dependency patients in inpatient care units. Therefore, the realities of these units point to the importance of the high-dependency degree, which is absent from Conselho Federal de Enfermagem (Cofen) Resolution N 293/2004, and which suggests its necessary revision, as pointed out in another study. ${ }^{27}$ 
Regarding allocation of nursing professionals in the period, it can be affirmed that there is under-allocation, with only three nurses and eight nursing technicians or assistants. This distribution of professionals in the study in the categories of nurses and nursing technicians and assistants occurred in the unit and during 13 months. As for the unit's current staff, the authors found a percentage of $25 \%$ nurses, which falls inside what is recommended for the realities of Brazil ${ }^{27}$ today $(20 \%$ to $25 \%$ ), and which is indicated for the care categories minimum, intermediary and high dependency. ${ }^{11}$ This, however, confirms a reality that falls well below what is stipulated in Cofen's resolution $\mathrm{N}$ $293 / 2004$, which states that, for minimum and intermediary care, there should be between $33 \%$ and $37 \%$ of nurses. In general, there are fewer nursing hours than what is desirable for quality and safety in nursing care. This is an important challenge for Brazilian nursing. ${ }^{27}$ This situation highlights an often overlooked fact, which is that necessary care is often not administered. When analyzing patient complaints in satisfaction surveys about nursing care received in the unit, one of the concerns was that explanations for many aspects of treatment were often neglected. Another revealing aspect was the reliance on companions for the performance of nursing care.

Another importance component of PRAXIS technology was the unit's performance assessment as a permanent practice from the perspective of continuous indicator improvement. User satisfaction with nursing assistance, as well as its visibility for the health team and the unit's users, has been a factor for professional motivation and satisfaction in the nursing team.

The recording and prevention of adverse events is a systematic process still to be conquered. There is actual fear that this device results in punishment measures, not in educational and preventive measures. Institutions should increasingly treat errors as organizational, not individual issues (which has already happened in some cases).

The rates of hospital-acquired infections in the unit seem high, but it is not possible to make a conclusive observation because there are no available data to compare equivalent realities. The outlook of hospital-acquired infection control in Brazil, published by Agência Nacional de Vigilância Sanitária, presents a general rate of 9\%. However, only 182 hospitals provided data in a scenario of more than 5,000 hospitals. ${ }^{28}$ According to the World Health Organization, $5 \%$ to $10 \%$ of patients admitted to hospitals acquire one or more infections. ${ }^{29}$ PRAXIS, in addition to displaying the unit's rates of infection on the electronic panel, also displays the type of prescribed precaution for each patient as a way to support and encourage proper measures in daily work. PRAXIS's GQUALI brings together user perception of care received and technical and organizational measures for safe care. Results and indicators are available on the unit's electronic panel for constant interaction with the professionals.

\section{CONCLUSION}

Use of the PRAXIS technology in an inpatient care unit since April 2013 makes it possible to confirm the suitability and accuracy of its guiding principles and components. The intervention evidenced the effects, because previously, among other things, the unit did not: have participative planning; classify its patients daily to organize nursing care according to their needs; use a permanent and scientific device for assessing the accuracy of the allocation of nursing professionals required in the unit; or apply indicators for measuring the unit's performance in key aspects, such as user satisfaction, adverse events, rates of hospital-acquired infection and others. PRAXIS technology made it possible to put these relevant aspects of inpatient unit management into practice, as shown in the results.

The authors conclude that consolidation of the technology and a comprehensive assessment of its impacts demand time and a maturation process. The study is limited by the fact that this is the technology's first use, which does not allow greater generalizations and demands a longer process with more widespread use for more consistent comparisons of its benefits in relation to present reality. It is expected that widespread use of the technology and its improvement will generate a critical mass capable of significantly improving performance in inpatient care units, thus creating a new standard and representing an effective contribution to the improvement of these practice environments, which are very important for the nursing profession and for the users of health services.

\section{REFERENCES}

1. Mintzberg H. Criando organizações eficazes: estruturas em cinco configurações. $2^{\mathrm{a}}$ ed. São Paulo (SP): Atlas; 2006. 
2. Bohmer M. Arquitetura e planejamento na gestão da saúde. Porto Alegre (RS): Bookmann; 2012.

3. Toussaint J, Gerard RA. Uma transformação na saúde: como reduzir custos e oferecer um atendimento inovador. Porto Alegre (RS): Bookman; 2012.

4. Ministério da Saúde (BR). Secretaria de Atenção à Saúde, Cadastro Nacional de Estabelecimentos de Saúde, Departamento de Informática do SUS. Consulta leitos. 2013. [cited 2013 Jul 30]. Available from: http://tabnet.datasus.gov.br/cgi/tabcgi. exe?cnes/cnv/leiintbr.def

5. Agência Nacional de Saúde Suplementar (BR). Caderno de informação da saúde suplementar: beneficiários, operadoras e planos. Rio de Janeiro (RJ): ANS; 2013.

6. Polit DF, Beck CT. Fundamentos da pesquisa em enfermagem: avaliação de evidências para a prática de enfermagem. $7^{\mathrm{a}}$ ed. Porto Alegre (RS): Artmed; 2011.

7. International Organization for Standardization (ISO). IEC 12207: Systems and software engineering. Software life cycle processes; 2008.

8. Souza VD, Driessnack M, Mendes IAC. An overview of research designs relevant to nursing: Part 1: quantitative research designs. Rev Latino-Am Enferm. 2007; 15(3):502-7.

9. Harris AD, McGregor JC, Perencevich EN, Furuno JP, Zhu J, Peterson DE, et al. The use and interpretation of quasi-experimental in medical informatics. J Am Med Inform Assoc. 2006; 13(1):16-23.

10. Conselho Federal de Enfermagem (BR). Resolução Cofen n. 293, de 21 de setembro de 2004. Fixa e estabelece parâmetros para o dimensionamento do quadro de profissionais de enfermagem nas unidades assistenciais das instituições de saúde. [cited 2013 Apr 01]. Available from: http:// novo.portalcofen.gov.br/ resoluo-cofen-2932004_4329.html

11. Fugulin FMT, Gaidzinski RR. Dimensionamento da equipe de enfermagem em unidades de internação. In: Harada MJCS, organizadora. Gestão em enfermagem: ferramenta para prática segura. São Caetano do Sul (SP): Yendis; 2011. p. 214-22.

12. Stanton MW, Rutherford MK. Hospital nurse staffing and quality. Rockville (US): Agency for Healthcare Research and Quality; 2004.

13. Vecina Neto G. Serviços de assistência direta ao paciente: internação. In: Vecina Neto G, Malik AM. Gestão em Saúde. Rio de Janeiro (RJ): Guanabara Koogan; 2011. p. 209-26.

14. Jennings BM. Patient acuity. In: Hughes RG. Patient safety and quality: an evidence-based handbook for nurses. Rockville (US): Agency for Healthcare Research and Quality; 2008. p. 621-7.

15. Staggs VS, He J. Recent trends in hospital nurse staffing in the United States. J Nurs Adm. 2013; 43(78):388-93.
16. Aiken LH, Sloane DM, Bruyneel L, Heede KV, Griffiths P, Busse R, et al. Nurse staffing and education and hospital mortality in nine European countries: a retrospective observational study. Lancet. 2014 May; 383(9931):1824-30.

17. Clarke SP, Donaldson NE. Nurse staffing and patient care quality and safety. In: Hughes RG. Patient safety and quality: an evidence-based handbook for nurses. Rockville (US): Agency for Healthcare Research and Quality; 2008.

18. Blegen MA, Goode CJ, Park SH, Vaughn T, Spetz $\mathrm{J}$. Baccalaureate education in nursing and patient outcomes. J Nurs Adm. 2013; 43:89-94.

19. McHugh MD, Berez J, Small DS. Hospitals with higher nurse staffing had lower odds of readmissions penalties than hospitals with lower staffing. Health Aff. 2013 Oct; 32(10):1740-7.

20. International Council of Nurses. ICHRN Policy Statement. Safe staffing levels: statement of principles [internet]. 2013 [cited 2014 Sep 10]. Available from: http://www.icn.ch/images/stories/documents/ pillars/sew/ICHRN/Policy_Statements/Policy_ statement_Safe_staffing_levels.pdf

21. Sherwood G, Zomorodi M. A new mindset for quality and safety: the QSEN competencies redefine nurses' roles in practice. Nephrol Nurs J. 2014 Jan-Feb; 41(1):15-22.

22. Ministério da Saúde (BR). Secretaria de Gestão Estratégica e Participativa. Política Nacional de Gestão Estratégica e Participativa no SUS - ParticipaSUS. $2^{\text {a }}$ ed. Brasília (DF): MS; 2009.

23. Ministério da Saúde (BR). Secretaria de Atenção à Saúde, Núcleo Técnico da Política Nacional de Humanização. HumanizaSUS: documento base para gestores e trabalhadores do SUS. $4^{\text {a }}$ ed. Brasília (DF): MS; 2010.

24. Magalhães AMM, Riboldi CO, Dall'Agnol CM. Planejamento de recursos humanos de enfermagem: desafio para as lideranças. Rev Bras Enferm. 2009 Jul-Ago; 62(4):608-12.

25. Fagan MJ. Techniques to improve patient safety in hospitals: what nurse administrators need to know. J Nurs Adm. 2012 Sep; 42(9):246-30.

26. Fugulin FMT, Gaidzinski RR, Kurcgant P. Sistema de classificação de pacientes: identificação do perfil assistencial dos pacientes das unidades de internação do HU-USP. Rev Latino-Am Enfermagem. 2005 JanFev; 13(1):72-8.

27. Fugulin FMT. Parâmetros oficiais para o dimensionamento de profissionais de enfermagem em instituições hospitalares: análise da resolução Cofen no. 293/04 [tese]. São Paulo (SP): Universidade de São Paulo, Escola de Enfermagem da USP; 2010.

28. Agência Nacional de Vigilância Sanitária (BR). Boletim Informativo sobre a segurança do paciente e qualidade assistencial em serviços de saúde. Brasília 
(DF): GGTES/Anvisa; 2011 [cited 2013 May 15] Available from: http://portal.anvisa.gov.br/wps/ wcm/connect/f72c20804863a1d88cc88d2bd5b3ccf0/
BOLETIM+I.PDF?MOD=AJPERES

29. Hinrichsen SL. Qualidade e segurança do paciente: gestão de riscos. Rio de Janeiro (RJ): Medbook; 2012. 